Article

\title{
The Great Discrepancy: Political Action, Sustainable Development and Ecological Communication
}

\author{
Dieter Konold * and Thomas Schwietring
}

Project Management Jülich, Forschungszentrum Jülich, 52425 Jülich, Germany; E-Mails: d.konold@fz-juelich.de (D.K.), t.schwietring@fz-juelich.de (T.S.)

* Corresponding author

Submitted: 4 September 2020 | Accepted: 22 December 2020 | Published: 26 February 2021

\begin{abstract}
The term 'sustainable development' was coined to denote a political goal some 40 years ago; debates about sustainability date back considerably further. These debates reflect the growing awareness of the destructive effects of human activities on the natural foundations of life. Numerous initiatives have been launched to trigger a turnaround, with the $2030 \mathrm{Agenda}$ and the SDGs being the latest attempt. However, substantial progress has been rather limited thus far. This discrepancy is the subject of the article. Starting from a historical overview of sustainability politics, the argument develops in three steps. First, it is shown that conventional conceptions to promote environmental change fall short in depicting the broader societal context. To provide a comprehensive picture of the challenges related to transformation processes, a theory of the functional differentiation of societies is presented in a second step. A systems theory perspective offers a convincing theoretical explication of the problem. Third, this approach is scrutinized with regard to the political system and the politics of sustainability. The key finding is that the specific functional logics of the different social subsystems must be taken into account when analysing sustainable development and the discrepancy between the aims and ambitions of (global) environmental policy and the visible consequences. On the one hand, the functional differentiation of modern society guarantees its high degree of effectiveness and flexibility. On the other hand, implementing fundamental change, such as a transition towards sustainability, is not simply a question of strategy or of political willingness and steering. Rather, there is a need for more elaborate explanatory instruments. As a result, we argue for a linking of theories of sustainable development and advanced social theory.
\end{abstract}

\section{Keywords}

environmental policy; functional differentiation; global governance; Niklas Luhmann; sustainability politics; Sustainable Development Goals; systems theory

\section{Issue}

This article is part of the issue "The 2030 Agenda for Sustainable Development: Transformative Change through Sustainable Development Goals?" edited by Thomas Hickmann (University of Utrecht, The Netherlands), Markus Lederer (Technical University of Darmstadt, Germany), Jens Marquardt (Technical University of Darmstadt, Germany), Sandra Schwindenhammer (Justus Liebig University Giessen, Germany) and Sabine Weiland (Catholic University of Lille, France).

(C) 2021 by the authors; licensee Cogitatio (Lisbon, Portugal). This article is licensed under a Creative Commons Attribution 4.0 International License (CC BY).

\section{Introduction}

Compared to almost any previous international political initiative related to sustainable development, the 17 Sustainable Development Goals (SDGs; United Nations, 2015) have been a tremendous success-at least in terms of sustained communication. Doubtlessly, the colourful and easily recognizable SDG logo contributes in no small part to this success. Viewed from a social sciences perspective, a cursory bibliometric analysis underlines the penetration of the SDG concept in comparison to its predecessors. A search in the Social Sciences Citation Index for the 1987 Brundtland Report Our Common Future (United Nations, 1987) produces less 
than ten hits annually since its publication. Searching for the 'Earth Summit' or 'Rio Summit' of 1992 shows 37 titles in 1992 and up to 23 hits per year in the years afterwards. The search for 'Millennium Development Goals' results in up to 214 hits per year, with an annual average of 104 . In contrast to these rather limited numbers, the search for 'Transforming Our World' and 'Sustainable Development Goals' produced up to 1,156 hits in 2019, with an annual average of 615 since 2015 . However, does this increased communication mean that the SDGs lead to more tangible consequences in terms of sustainable development than earlier declarations and strategies? Do they contribute in a more effective and lasting way to shaping practical policies than previous debates, programmes and headwords did?

In retrospect, the former secretary general of the Brundtland Report's commission, Jim MacNeill, was stunned by the "new growth industry...of seminars and conferences around the world" - inevitably this article is a part of this-but stated that, if any progress towards more sustainable development had actually been made at all, it were only rather tiny steps forward (MacNeill, 2013). Part of MacNeill's sobering account is a plea for more courageous political action and constant pressure by civil society. Both are typical and widespread appeals for 'what has to be done' and by whom. The SDGs are an emphatic new attempt to push such action forward. But are they, from a social science perspective, a sufficient approach?

The tentative observations outlined above lead right to the subject of this article. Looking back at the history and even prehistory of (political) debates on sustainable development (Section 2), we point to the discrepancy between the ongoing and, since the 1970s, greatly expanding debate on sustainability and the merely isolated and fragile advances - if there have been advances at all-towards sustainable development (Section 3). While there is a large amount of debate on what needs to be done, the question rarely asked is: Why has hardly any effective progress been made? We refer to the ambitious systems theory of Niklas Luhmann (1984, 1997, 2002, 2013) and his studies $(1986 / 1989,1992)$ addressing the preconditions of ecological communication (Section 4) as an analytical tool to get a grip on this puzzle, without referring to political failure, egoism or other explanations derived from everyday world experiences. We then return to our initial question of why promoting sustainability is so challenging and discuss possible advantages and limits of a systems theory perspective (Section 5). We conclude by arguing that a clear conception of what a system is, and how different systems interact, is a prerequisite for the frequently demanded 'systemic' approaches in sustainability research.

\section{A Brief Look Back: Sustainability as a Governmental Task}

Historically, there are several prominent starting points for the increasing awareness of environmental, ecolog- ical and sustainability issues. From a global perspective, they differ depending on cultural and societal contexts. If one wants to highlight a starting signal for Western industrialized countries, 1972 would be a plausible candidate to date the beginning of a broader public debate. The United Nations Conference on the Human Environment took place in Stockholm in June 1972, and the Club of Rome published its first report The Limits to Growth in the same year (Meadows, Meadows, Randers, \& Behrens, 1972). Of course, there had been voices articulating the need for nature conservation and demanding substantial action against environmental pollution much earlier. Policy measures against air pollution were initiated beginning in the late 1940s. Around that time 'smog' became a popular term to describe a healththreatening phenomenon emerging in cities around the world, for example, Los Angeles and London, mainly related to the rapidly growing number of vehicles with combustion engines. California began to establish 'air pollution control districts' in 1947, and a nation-wide Air Pollution Control Act was issued in the United States in 1955 (Air Pollution Control Act, 1955). The destructive effects of the industrial lifestyle had been put on the global agenda.

This development was reflected by a growing number of publications dealing with ecological topics that gained huge public attention, particularly from the $1960 \mathrm{~s}$ onwards. Probably the most important, certainly one of the most influential books in this context was Silent Spring by Rachel Carson (1962). Another example of an early warning about environmental problems caused by humankind that spurred debates both within science and the political sphere was a lecture by Lynn White with the programmatic title "The Historical Roots of our Ecological Crisis" (White, 1967). Contemporary concerns over sustainability are based on an increasing awareness of the negative consequences accompanying population growth in combination with rapid economic growth, and the constantly rising level of consumption in the postwar period. Political attempts to react to these problems through regulation and the creation of new environmental authorities are another aspect of these origins. A third aspect was the emergence of 'ecology' as an independent scientific discipline analysing the relationships between organisms and their environment (for a brief critical review, see Biermann, 2020).

The term 'sustainability' has its roots even further back in history. Usually, at least in the German context, its first use is ascribed to Hans Carl von Carlowitz (2013) and his 1713 book Sylvicultura Oeconomica on the problems of de- and afforestation. Even though it may be disputed whether Carlowitz really 'invented' the notion, and whether his understanding of the concept was as comprehensive as was later credited to him (Kaden, 2012), sustainability became a well-known principle in central European forest management in the 18th and 19th centuries (Grober, 2010). Interestingly, environmental historians point out that regulating the use of scarce 
resources like wood and water was a decisive impetus for the emergence of early state authority in different parts of the world (Radkau, 2000, pp. 107-182; see also Du Pisani, 2006). From this perspective, statehood was a response to environmental challenges that required collective action. In other words, the necessity to have binding rules to deal with issues of sustainability provided the legitimacy for state authority. This finding is all the more remarkable as the modern state seems to have lost exactly this core competence.

\section{The Underlying Problem: Sustainability and Responsibility}

The question whether or not humankind is-or ever was-able to act in a sustainable way and to conserve its environment is the subject of ongoing discussions in many disciplines of science. Those who tend towards a negative answer often refer to the tragedy of the commons' (Hardin, 1968) as the reason why human action usually goes hand in hand with an overexploitation of natural resources. The insight that the quest for individual prosperity does not at all lead to optimal societal solutions through an 'invisible hand' or some other mechanism-as famously depicted by Adam Smith-became a very powerful explanation for the non-sustainable behaviour of human beings, notably in economics, although its author was a biologist. Thanks to the oeuvre of Elinor Ostrom (e.g., Ostrom, 1990), we know that there is no such automatism and that lots of cases show how actors in very different settings manage to establish institutions, and in doing so overcome the alleged tragedy. However, we also know that the efficiency of such institutions depends on the circumstances. The more people, interests and ideas are affected, the harder it is to establish and to implement rules that constrain individual behaviour. While in small entities and communities, like households, cooperatives or villages, some kind of social control-traditions, mutually agreed rules over fair sharing, etc. - can quite easily ensure that everybody abides by the rules, larger societal structures are more likely to face free rider problems. The size of social units is one important factor with regard to the prospect of success for sustainability. The economic system is a second important factor. Large societies must rely on different and more abstract structuring mechanisms, and the feedback between the physical environment and society is much less immediate. Furthermore, at the risk of oversimplification, the more the economic system is geared towards profit or production, the lower the value placed on goods that are not priced, such as fresh air or clean water. In his seminal analysis, Karl Polanyi (1944/1957) describes the 'great transformation' that took place over the course of the industrial revolution and resulted in a new type of economy. This market economy was no longer embedded in social institutions that had grown over centuries: "The transformation implies a change in the motive of action on the part of the members of society: for the motive of subsistence that of gain must be substituted" (Polanyi, 1944/1957, p. 41). We share Polanyi's view that the importance of this social change can hardly be overestimated. In the following section, we offer a systems theory approach to show how fundamentally the differentiation of the economic system altered the rules of the game with respect to society and sustainability.

Coming back to our initial argument, there are good reasons to adhere to the year 1972 as a starting point for our investigation as it marks the beginning of genuine sustainability politics. In the 1970 s, previously isolated problems like air pollution, polluted rivers or nature conservation were brought together and discussed as part of the problematic Western model of economic and industrial development, and of mass consumption as a whole (Meadows et al., 1972; White, 1967). A new characteristic of this debate was its broad and well-founded basis. While earlier observations about ecological problems often lacked clear empirical evidence, by the 1970 s the scale of environmental degradation had become obvious. Science produced more and more data and knowledge about the impacts of human conduct. Erhard Eppler, until 1974 Minister for Economic Cooperation and Development in Germany, lamented in 1975-44 years before the Fridays for Future movement formedthat never before had there been such a discrepancy between what science said and what politics did (Eppler, 1975). However, the 1970s saw the rise of international environmental diplomacy. Following the 1972 United Nations Conference on the Human Environment, the United Nations Environment Programme was founded. The United Nations Environment Programme played a crucial role in preparing the 'World Conservation Strategy' that was published in 1980 and for the first time used the term 'sustainable development,' seven years before it became famous in the Brundtland Report (United Nations, 1987).

Almost half of a century has passed since 1972. Irritatingly, at the end of these five decades we have arrived at little more than a recognition of the existence of 'planetary boundaries' (Steffen, Rockström, \& Costanza, 2011), which sounds nearly unchanged since the 1972 diagnosis of 'limits to growth.' From the viewpoint of practical politics, this disillusioning conclusion seems inescapable. However, viewed from a broader historical perspective, it is doubtful whether 50 years are really a sufficient amount of time for a fundamental shift in the economic base of modern societies to occur. If sustainability refers to a substantial reorientation-and not merely a little less consumption, a little more efficiency in the use of energy and material resources and slightly cleaner production-the task ahead requires no less than a profound change in social patterns that have developed over centuries.

The last 50 years have seen the rise of civil movements, new fields of research, numerous publications, guidelines, regulations and bills. In particular, they have 
seen constant efforts by the United Nations to push forward a global sustainability agenda and to agree on goals, criteria and indicators of sustainable development. From a self-critical perspective, one could describe this development as the institutionalization of sustainability. New national and international organizations, research institutes, political parties and specialized ministries have been set up. These in turn constantly produce communications and outputs in the form of large conferences, strategies and international agreements (which eventually become ratified decades later, or not). However, it is quite evident that this has not led to a tangible and lasting shift towards sustainable development. Therefore, the pivotal question is: Why is it so difficult to steer societal development in a sustainable direction? In the following section, we will suggest a theoretical explanation as to why sustainability has constantly been on the agenda for several decades and has become a well-established field of politics, while, at the same time, the per capita use of energy and material resources steadily increases, climate change and the loss of biodiversity continue unabated and the oceans turn into a great rubbish dump.

The ongoing and worsening ecological crisis has led to a shift in some parts of the debate away from the quest for sustainable development and towards a more radical perspective. The issue no longer seems to be how we avoid transgressing planetary boundaries or 'tipping points' but when we will do so and what sort of crisis this will set off (Franzen, 2019). For some observers, we have already reached an irreversible dynamic towards a global disaster. Whether this is the case or not, the question of why all efforts of science and of the political sphere have been in vain remains. In the following section, we will discuss possible answers and explanations.

\section{An Attempt to Explain: Functional Differentiation of Modern Societies}

Compared to the large number of suggestions for how to attain sustainable development, and the even larger amount of criticism of existing policies, there are relatively few substantial analyses of why we see such little progress. Everyday explanations, like a lack of interest (by those who do not yet suffer from the effects of rising sea levels or temperatures and extreme weather events), the incompetence of politicians and their advisors (blamed for having too narrow and short-sighted a focus), or hesitancy (preventing people from taking action before others do), are rather pre-theoretical and ad hoc interpretations. The mutual weighing up of ecology and economy is a widespread occupation for commentators and politicians, but does not in reality shed any light upon the problem.

More promising could be a historical perspective of the rise of industrialized, capitalist societies and the origin of their urge to constantly produce and gain more and more as an end in itself. It is probably the most prominent issue of classical social sciences from Adam Fergusson through Karl Marx to Max Weber and Karl Polanyi: Why and how did modern, rationalized, capitalist societies evolve? Despite all of the differences in their explanations, they agree in one point. The origin of this type of society, with all its contradictions and ambivalences, is a historical puzzle and by no means a self-explanatory and inevitable historical process. In order to explain this unique development, social sciences refer to factors ranging from technology through religion to climate change (Blom, 2019). They all have in common that they describe a process spanning several centuries. If sustainable development means a fundamental transformation of this type of societies that have emerged over the course of history, and of their focus on economic growth as a means in and of itself, the temporal horizon has to be widened. Looked at from this historical perspective, five decades of discussion appear a rather brief period of time and certainly too short a phase to revise a historical process.

A contemporary theory, which may be used to explain the discrepancy between effort and success in the field of sustainability, is the theory of functional differentiation (Schimank, 2005; Schimank \& Volkmann, 2015). What is probably its most elaborate version - the combination of the theory of functional differentiation with general systems theory by Niklas Luhmann-may be an appropriate tool to provide an answer to our question (Luhmann, 1985, 1987). Bringing together a range of theoretical components, it describes modern societies as an interplay of self-referring and even self-organizing societal subsystems (Luhmann, 1984, 1997, 2013). For Luhmann, these systems are-in a sharp contrast to the older theory of structural functionalism by Talcott Parsons $(1951,1971)$ - not defined by a function they fulfil for society at large, but based on some sort of monopoly of communication. Each system organizes itself around a 'medium' and a 'code.' Whenever this binary code is used in a communication to describe any part of reality, this can be regarded as an operation of the respective system by which the system itself is reproduced. Societal systems are 'closed' systems because their manner of operation is self-referring. The code guarantees that each communication is unambiguous and can be answered only by referring to the same code. The economic system, for example, is based on the guiding difference between 'paying' and 'not paying' as its code (Luhmann, 1988). Whenever one applies this difference to communicate about whatever aspect of reality, this communication becomes part of the economic system. The other way around, the economic system, like any other societal subsystem, can 'observe' or handle reality only by means of its particular code. Social systems organize and constitute themselves by this mode of communication, not by formal institutions like companies, government bureaus, political parties or parliaments.

The 'operational closure' of each subsystem is the result of a historical process, an interplay of social struc- 
ture and historical semantics (Luhmann, 1980, 1981, $1989,1995)$. The historical account of the semantic and structural basis of the operational closure of social systems is the empirical fundament of Luhmann's theory (Schwietring, 2006). It explains which sort of semantics became a binary code and a crystallization point of the operational closure of a social subsystem. The number of such subsystems is neither limited nor unlimited. Luhmann's analysis does not claim to have described all of them, nor does it rule out that further subsystems may evolve in future. For the present, he analysed the subsystems of economy, politics, science, law, art, education, and religion. Functional differentiation, as a mode of societal order by means of communication, is no longer limited to societies defined by national borders. It has a tendency to spread globally and to include all sorts of communities and territories. The differentiation of societal subsystems tends to shape an all-encompassing world society (Heintz, Münch, \& Tyrell, 2005; Luhmann, 1975; Stichweh, 2000; for a critical review, see Holzinger, 2018). This, by the way, is another aspect rendering the theory relevant for questions of sustainable development in terms of planetary boundaries (Engels, 2003).

Turning back to our question, this variant of differentiation theory can explain the dynamic, efficiency, and, at the same time, the stability of modern societies. Whatever may happen, the respective systems can only observe it by means of their constituting code. This is the limitation and, at the same time, the strength of each system. To stay with the example of the economic system, it is unable to handle questions of social justice or environmental pollution except in terms of its constitutive code 'paying/not paying' (Luhmann, 1986/1989, pp. 6-7, 15-21, 51-62, 1988). Exactly because it is closed and self-referring, it is highly flexible and independent from other societal subsystems or ecological crisis, for example. For each system, all other systems are merely a part of its diffuse 'environment.' Each system conceives the operations of other systems only as some sort of noise. Of course, this noise can irritate the system, but its only way to respond to an irritation caused by its environment is an internal operation based on its own code or guiding difference. The internal 'resonance' an external event-be it a change in government or an environmental issue-can set off within a system depends entirely on its internal code (Luhmann, 1986/1989, pp. 44-50, 2013, pp. 28-39). This is, in the terms of this variant of functional differentiation theory, the reason why there is no hierarchy between the systems and why there is no way one system can determine or steer the operations of another system.

To put it in a simple but illustrative example: Growing public concerns over plastic waste together with political pressure led to a self-commitment undertaken by companies in the retail sector in Germany to ban plastic bags from their stores. What seemed to be a step forward was not a sign of substantial change but merely a reaction in terms of paying/not paying due to the fear of losing customers. At the same time, retailers started to paste plastic stickers on fruits and vegetables to give them some sort of 'label.' Obviously, a demand for sustainability does not provoke a re-orientation within the economic system but only causes some kind of selective operation following its internal code. Forcing economic actors to reduce carbon dioxide emissions must by no means lead to sustainable alternatives. Based on the theoretical perspective applied, this comes as neither surprise nor disappointment but is exactly what was to be expected.

The argument of the absence of hierarchy between systems is important to answer our question. Described by means of the theory of functional differentiation, there is no steering centre and no privileged lever that can be used to turn the dynamic of functionally differentiated societies in a certain direction (Luhmann, 1986/1989, pp. 106-114, 2013, pp. 40-48). Any attempt to restructure the dynamics of social systems, for example, towards less resource use, less pollution or less consumption, will be answered by the different social subsystems in the only way each system can operate. The economic system, for example, will turn it into a question of paying/not paying.

Functional differentiation accounts for the historically unique dynamic and effectiveness of modern societies, for example, in terms of material wealth, technological innovation and personal self-determination. At the same time, functional differentiation makes it extremely difficult, if not unlikely, to act in an anticipatory and to some degree self-restraining way that is synonymous with sustainable development. The crucial point for the study of sustainability politics is that changing the functional logic of differentiated subsystems is simply beyond the scope of political action.

\section{A Systems Theory Perspective: Promises and Constraints}

Luhmann's theory of social systems offers a valuable explanation for the functionality of modern societies. It helps us understand why incidents, changes and even life-threatening devastation in the physical environment-that is, outside of society in terms of social systems-do not automatically cause any societal reaction. In fact, as long as there is no communication about these matters, they literally do not exist as a societal question (Luhmann, 1986/1989, pp. 34-35). In the introduction we demonstrated that communication regarding ecological problems is not a new phenomenon but that, due to the specific logics of the different subsystems of society, communication does not necessarily evoke resonance (i.e., a specific reaction), nor does it inevitably cause the reaction that is expected or wanted. Rather, each system will react according to its respective coding. What is more, resonance in one subsystem does not have immediate consequences for the rest of society. Against this background, it is not surprising that transformations, particularly when affecting 
society as a whole, do not occur easily and quickly. The widely shared view that sustainability goals, once they are politically adopted, only have to be implemented is, therefore, rather naïve.

Despite its explanatory power, Luhmann's model has rarely been applied to issues of environmental and sustainability policy. One reason for this is that this theoretical framework is not suitable to offer recipes for what should be done. Rather, it provides sound explanations for why there has been-despite all political efforts and technological and economic developments-so little, if any, substantial progress. Furthermore, his work is not very well-known beyond the German-speaking sociology community, not least because only parts of his monumental opus have been translated and his highly theoretical reasoning may become even harder to follow upon translation into English (see also Blühdorn, 2000; Mathur, 2005). Another reason why Luhmann is not very popular in political science might be his obvious reluctance to acknowledge the research and findings of the discipline. While he was legendary for evaluating and commenting on vast amounts of literature from nearly all fields of science in his famous 'card index,' Luhmann made no effort to link his theory to existing and potentially compatible approaches in political science. This is regrettable, as there would have been numerous interfaces at which to connect his systems theory with theories on political decision-making, institutional varieties, agenda-setting or different modes of governance.

In political science, attention focuses on Luhmann's concept of the political subsystem of society. For him, the political system, like any other subsystem, functions according to a binary code which guides every form of political communication. In the case of the political system, this is the question of having or lacking political power. Considering the manifold factors that are relevant for political action, this assumption seems to be rather simplistic. Reducing complexity is an important function of theories but in using such a narrow concept there is a danger that central aspects of politics are ignored. It is questionable whether the struggle for power and influence-whatever that may mean-is the decisive driving force of 'classical' politics. However, doing politics has changed and become even more diverse in recent decades. Different actors are involved in very different ways in decision-making processes. The term 'governance' has become popular to describe these interactions and interdependencies (Kooiman, 2003; Mayntz, 2006; Rosenau \& Czempiel, 1992). Lobby groups, expert networks, advisory bodies, non-governmental organizations and other non-state actors all pursue their respective interests, but it seems doubtful whether all of these activities, which (for a political scientist) uncontroversially form part of the political system, can be captured by a mere focus on power. Luhmann's coding, therefore, is a fine example of parsimony in theory construction but it might be inadequate to cover the full range of politics and political communication.
Luhmann applied his systems theory approach to analyse the conditions under which modern societies can respond to ecological threats. This study dates from the mid-1980s (Luhmann, 1986/1989). He opened up a seminal theoretical perspective on the systemic barriers to sustainable development, even though in retrospect some of his judgements-for example, on the lack of credibility of the green parties-have proven to be rather short-sighted. Only a few years after the environmental movement had started to institutionalize itself in formal organizations and non-profit research institutes, Luhmann remained sceptical as to whether ecological problems had the capacity to irritate social systems with far-reaching effects (Luhmann, 1986/1989, p. 32).

When we talk about ecological threats today, it is clear that we do not refer primarily to ecological disasters like oil tanker collisions or core meltdowns in nuclear power plants. Ecological risks arise from normal industrial processing and everyday consumption. Contrary to Luhmann's intention, one could argue that due merely to functional differentiation the economic system cannot deny its responsibility (Bendel, 1993, p. 276). Notwithstanding these points of criticism, we believe the theoretical perspective remains valuable when considering the discrepancy between the widespread sustainability rhetoric and the lack of substantial results. Following Luhmann, the obstinacy of functionally differentiated systems may contribute considerably to the lack of success. The high degree of decoupling from their environment, which renders functionally differentiated systems effective, also accounts for their inability to grasp the consequences of their operations in terms of sustainability. First attempts have been made to apply Luhmann's perspective in this context (Büscher \& Japp, 2010), and we think this could be a promising starting point for further research.

Luhmann's theory of ecological communication might offer a very useful framework to assess the state of and developments in the quest for sustainability. This framework might serve as a kind of meta-theory to reveal the basic structure of modern societies and the fundamental challenges to be overcome when profound transformations are intended. Within this overall concept, specific issues might require further refinement. Above all, this concerns the questions of why and how resonance and reaction in the different subsystems of society are generated. It would go far beyond the scope of this article to develop such theoretical synergies in detail but possible enhancements are obvious. The analysis of political stability and change, of transitions and policy shifts, of factors that trigger and conditions that foster or hamper such developments are at the core of political science (e.g., Baumgartner \& Jones, 1993, 2002; Capano \& Howlett, 2009; Kingdon, 1984; with regard to sustainability, see Meadowcroft, 1999). Combining a systems theory perspective with approaches to deal with change and dynamics could, therefore, serve to launch a fruitful debate about sustainability politics. While the concep- 
tion of differentiated systems with specific constitutive codes that inhibit direct communication between these systems can explain the basic functioning principles of society, the theory is rather blind to new social developments and changes. While Luhmann scrutinized the historical genesis of functional differentiation, the corresponding semantic codes and the operational closure of societal systems, he considered substantial future changes to the basic structure of differentiated systems unlikely. From this perspective, all kinds of events like news about ecological catastrophes, public protests, and political reactions appear as a succession of communications relying on the foundational coding of the respective systems, whereas the overall state of society is-or seems to be-stable. Such a view might tend to underestimate the dynamics of novel phenomena. With regard to the political system, this could be the reason why Luhmann was highly sceptical of the system's ability to react to ecological problems within the time frame set by elections. In his opinion, the political weighing of interests would almost by necessity disadvantage ecological concerns. As indicated above, at this point systems theory might benefit from theoretical and empirical findings derived from political science research to explore conditions under which paradigm and policy shifts do happen.

Research on this topic would be even more desirable as new environmental movements are on the rise globally and ecological matters are gaining in importance. It is probably not a particularly bold statement to say that the irritation of the political system with regard to sustainability will increase considerably in the coming years. Applied in this manner, the theory of functional differentiation may offer insights less pessimistic than Luhmann's own conclusion. However, this does not alter the fact that political decisions such as adopting the SDGs are operations of the political system that have no direct effects on other systems unless another system observes the political operations applying its own code.

In Luhmann's theory, a complementary element to the self-referring closure of social systems is their mutual 'structural coupling.' Operationally closed systems are constantly irritated by their 'environment,' especially by the impenetrable complexity of other systems. It is important to keep in mind that Luhmann uses the term 'environment' not to refer to the natural surroundings of society but to any sort of communication which takes place outside of a specific system, that is, communications that follow a separate coding (Luhmann, $1986 / 1989$, p. 22,1997 , pp. 66-67). The political system, for instance, may react nervously to a decreasing growth rate. As throughout his work, in Ecological Communication, Luhmann (1986/1989) dedicates much more attention to the operational closure of functionally differentiated systems than to their structural coupling. Usually, he only gives some hints. He states that, for example, the economic system reacts immediately and inevitably to the scientific system (Luhmann, 1986/1989, p. 117). What Luhmann has in mind are technical inven- tions. A potentially disruptive invention emerging from the scientific system will trigger the economic system to adopt it as quickly as possible. Unfortunately, Luhmann does not elaborate on this coupling any further. Scientific knowledge about excessive emissions, unsustainable resource use or the potentially hazardous side-effects of industrial production do not stimulate the economic system to the same extent as technical inventions. Obviously, scientific findings only become an issue for the economic system insofar as its 'paying/not paying' code is affected.

While the debate on sustainability might profit from sound theoretical perspectives derived from the social sciences, the social sciences have to theorize about the relationship between social and ecological systems. Recent approaches tackle the classical dichotomy of humans and the environment by framing interconnections as issues of the 'Anthropocene' or an 'earth system' (Biermann, 2020). Such concepts considerably widen our understanding of the fundamental difficulties in deliberating the roles and positions of academic disciplines. Nevertheless, we doubt that these notions can be conceived theoretically as systems and that the systems' borders can be dissolved terminologically. Rather, from a systems theory perspective one pivotal question is whether there could be some sort of structural coupling of social and ecological systems that triggers evolutionary dynamics towards sustainability. We are aware of the theoretical challenges this may involve. Ecological and social systems do not have much in common apart from the term 'system.' Social systems are closed systems, and they operate by 'communication' and 'sense.' Ecological systems, in contrast, are systems of an entirely different type. They are open systems and operate in different ways with different media. The closure of social systems means that their evolution decoupled itself from immediate dependence on any sort of environment. Nowadays, as the limits of our planet come into sight, a new type of mutual dependency becomes obvious. Integrating advanced social systems theory into the debate on sustainability may prove fruitful for a theoretically informed analysis of where we are going. The task is to find a way to theorize about the coupling or interdependency of ecological and social systems without reducing one of these system levels to a diffuse or negligible 'environment' of the other.

\section{Conclusions}

We have tried to show that the theory of functional differentiation explains convincingly the discrepancy between sustainability rhetoric and practical outcomes. In contrast to widespread notions of 'systemic' or 'system as a whole' approaches, it offers a theoretically sound basis for the use of the concept 'system.' The difference between systems and their environment is conceptualized in a-still provocative-way that clarifies why a system may rely on some sort of environment but is 
unable to access or control this environment in a planned manner. To comprehend systems as closed, self-referring operational entities is not a sign of a lack of holistic or 'systemic' thinking. Quite the reverse, it is the result of a thorough application of systems theory. Unfortunately, the findings this dedicated systems theory approach suggest are not very encouraging.

So where do we go from here? What do these theoretical considerations mean for far-sighted sustainability politics and the attainability of political targets like the SDGs? Integrating Luhmann's theory of social systems into the debate on the SDGs, and sustainable transformation in general, forces us to reformulate frequently asked questions in a slightly different manner. Instead of asking: 'How do we overcome national egoism in politics?,' we should ask: 'Under what circumstances are decisions in favour of sustainability rewarded politically, that is, in terms of power?' Instead of engaging in ever more political arguments, scientists should ask, for instance: 'Under which conditions does scientific knowledge provoke resonance in other systems?' Probably the most crucial question concerns the economic system: 'How might the conservation and restoration of ecosystems pay off in terms of the 'paying/not paying' code of the system?'

In order to deal with these questions, we have to abandon the idea of society as a centred, organized, steerable totality. Consequently, we have to conceptualize the relations of human activities, ecosystems and even planetary geophysical cycles in a much more differentiated manner, adopting more complex notions of systems and the interplay of systems. Appeals to 'common efforts' in the political realm or calls for an integrated analysis of 'socio-ecological systems may sound convincing at a first glance. However, they not only ignore fundamentally opposed interests on a global scale, they also tend to conceal the complexity of the interplay between different systems within society, and the even greater intricacy of separate system levels like ecological and social systems.

Such an understanding of society will help us to assess the attainability of the SDGs. The idea behind the SDGs is that sustainability is a means to pursue a multitude of targets simultaneously. Even more, the preamble to the 2030 Agenda stresses a holistic view of 'humanity and the planet' based on people, planet, prosperity, peace and partnership (United Nations, 2015). It is an impressive declaration of humanity. The political system may be able to convert the pleasing sound of these alliterative components into the system's currency of gaining power. However, it is only the system's internal currency. As with many terms, power has a distinct meaning in Luhmann's systems theory and does not necessarily comprise the ability to force other social systems to obey political guidelines. The SDGs are a piece of communication of the political system, written in political language. In order to make them function and implementable, they must be translated and made compatible with the currencies-or ruling codes-of the oth- er affected subsystems, above all the economic system. Only if this succeeds will there be a sustained impact of the 2030 Agenda.

Functional differentiation of societies is not simply an obstacle to sustainability. It is the historical process that led to the independence of science, rule of law, personal freedom and democratic mechanisms to distribute and control power. To argue in favour of an elaborate theory of functional differentiation as an alternative to moral appeals or theoretically rather weak claims for holistic perspectives does not imply the abandonment of the goal of transformation towards sustainability. We merely suggest a theoretical approach that is as intricate as its subject.

\section{Acknowledgments}

An earlier version of this article was presented at a conference of the German Political Science Association. We are grateful to the participants of the event for many valuable comments. Advice and helpful comments were also provided by three anonymous reviewers and the Academic Editors. Special thanks go to our colleague David Butler Manning who supported us with his expertise and language skills.

\section{Conflict of Interests}

The authors declare no conflicts of interest.

\section{References}

Air Pollution Control Act, Pub. L. 84-159, 69 Stat. 322 (1955).

Baumgartner, F. R., \& Jones, B. D. (1993). Agendas and instability in American politics. Chicago, IL: University of Chicago Press.

Baumgartner, F. R., \& Jones, B. D. (2002). Policy dynamics. Chicago, IL: University of Chicago Press.

Bendel, K. (1993). Funktionale Differenzierung und gesellschaftliche Rationalität: Zu Niklas Luhmanns Konzeption des Verhältnisses von Selbstreferenz und Koordination in modernen Gesellschaften [Functional differentiation and societal rationality: On Niklas Luhmanns' conception of the relation of selfreference and co-ordination in modern societies]. Kölner Zeitschrift für Soziologie und Sozialpsychologie, 45(2), 261-278.

Biermann, F. (2020). The future of 'environmental' policy in the Anthropocene: Time for a paradigm shift. Environmental Politics, 21(2), 1-20. http://dx.doi.org/ 10.1080/09644016.2020.1846958

Blom, P. (2019). Nature's mutiny: How the little ice age of the long seventeenth century transformed the West and shaped the present. New York, NY: Liveright Publishing Corporation.

Blühdorn, I. (2000). Post-ecologist politics: Social theory and the abdication of the ecologist paradigm. Lon- 
don and New York, NY: Routledge.

Büscher, C., \& Japp, K. P. (Eds.). (2010). Ökologische Aufklärung: 25 Jahre "Ökologische Kommunikation" [Ecological enlightenment: 25 years 'Ecological communication']. Wiesbaden: VS Verlag für Sozialwissenschaften.

Capano, G., \& Howlett, M. (2009). Introduction: The determinants of policy change: Advancing the debate. Journal of Comparative Policy Analysis: Research and Practice, 11(1), 1-5. http://dx.doi.org/ 10.1080/13876980802648227

Carlowitz, H. C. V. (2013). Sylvicultura oeconomica oder Haußwirthliche Nachricht und Naturmäßige Anweisung zur Wilden Baum-Zucht [Forest economy or news and advice on natural cultivation of wild trees]. München: Oekom.

Carson, R. (1962). Silent spring. Boston, MA and Cambridge, MA: Houghton Mifflin Company and The Riverside Press.

Du Pisani, J. A. (2006). Sustainable development: Historical roots of the concept. Environmental Sciences, 3(2), 83-96. http://dx.doi.org/10.1080/ 15693430600688831

Engels, A. (2003). Die geteilte Umwelt: Ungleichheit, Konflikt und ökologische Selbstgefährdung in der Weltgesellschaft [The shared environment: Inequality, conflict, and ecological self-endangering in world society]. Weilerswist: Velbrück.

Eppler, E. (1975). Ende oder Wende: Von der Machbarkeit des Notwendigen [End or change: On the feasibility of the necessary]. Stuttgart: Kohlhammer.

Franzen, J. (2019). Wann hören wir auf, uns etwas vorzumachen? [What if we stopped pretending?]. Berlin: Rowohlt.

Grober, U. (2010). Die Entdeckung der Nachhaltigkeit: Kulturgeschichte eines Begriffs [The discovery of sustainability: Cultural history of a concept]. Munich: Kunstmann.

Hardin, G. J. (1968). The tragedy of the commons. Science, 162(3859), 1243-1248. http://dx.doi.org/ 10.1126/science.162.3859.1243

Heintz, B., Münch, R., \& Tyrell, H. (Eds.). (2005). Weltgesellschaft: Theoretische Zugänge und empirische Analysen [World society: Theoretical approaches and empirical analysis] [Special issue]. Zeitschrift für Soziologie Sonderband, 34, 1-502.

Holzinger, M. (2018). Warum die Weltgesellschaft nicht existiert: Kritische Reflexionen zu einigen empirischen und epistemologischen Problemen der Theorie der Weltgesellschaft [Why world society does not exist: Critical reflexions on some empirical and epistemological problems of the theory of world society]. Kölner Zeitschrift für Soziologie und Sozialpsychologie, 70(2), 183-211.

Kaden, H. (2012). Zur "Erfindung" des Begriffs "Nachhaltigkeit": eine Quellenanalyse [On the "invention' of the term 'sustainability': A source analysis]. Sächsische Heimatblätter: Zeitschrift für sächsis- che Geschichte, Denkmalpflege, Natur und Umwelt, 58(4), 384-391.

Kingdon, J. W. (1984). Agendas, alternatives, and public policies. Boston, MA: Little Brown and Co.

Kooiman, J. (2003). Governing as governance. London and Thousand Oaks, CA: Sage.

Luhmann, N. (1975). Die Weltgesellschaft [The world society]. In N. Luhmann (Ed.), Soziologische Aufklärung 2 [Sociological enlightenment 2] (pp. 145-171). Opladen: Westdeutscher Verlag.

Luhmann, N. (1980). Gesellschaftsstruktur und Semantik: Studien zur Wissenssoziologie der modernen Gesellschaft, Band 1 [Societal structure and semantics: Studies in the sociology of knowledge of modern society, vol. 1]. Frankfurt: Suhrkamp.

Luhmann, N. (1981). Gesellschaftsstruktur und Semantik: Studien zur Wissenssoziologie der modernen Gesellschaft, Band 2 [Societal structure and semantics: Studies in the sociology of knowledge of modern society, vol. 2]. Frankfurt: Suhrkamp.

Luhmann, N. (1984). Soziale Systeme: Grundriss einer allgemeinen Theorie [Social systems: Outline of a general theory]. Frankfurt: Suhrkamp.

Luhmann, N. (Ed.). (1985). Soziale Differenzierung: Zur Geschichte einer Idee [Social differentiation: On the history of an idea]. Opladen: Westdeutscher Verlag.

Luhmann, N. (1987). Soziologische Aufklärung 4: Beiträge zur funktionalen Differenzierung der Gesellschaft [Sociological enlightenment 4: Contributions to functional differentiation of society]. Opladen: Westdeutscher Verlag.

Luhmann, N. (1988). Die Wirtschaft der Gesellschaft [The economy of society]. Frankfurt: Suhrkamp.

Luhmann, N. (1989). Ecological communication (J. Bednarz, Jr., Trans.). Cambridge: Polity Press. (Original work published 1986)

Luhmann, N. (1989). Gesellschaftsstruktur und Semantik: Studien zur Wissenssoziologie der modernen Gesellschaft, Band 3 [Societal structure and semantics: Studies in the sociology of knowledge of modern society, vol. 3]. Frankfurt: Suhrkamp.

Luhmann, N. (1992). Ökologie des Nichtwissens [Ecology of the lack of knowledge]. In N. Luhmann (Ed.), Beobachtungen der Moderne [Observations of modernity] (pp. 149-220). Opladen: Westdeutscher Verlag.

Luhmann, N. (1995). Gesellschaftsstruktur und Semantik: Studien zur Wissenssoziologie der modernen Gesellschaft, Band 4 [Societal structure and semantics: Studies in the sociology of knowledge of modern society, vol. 4]. Frankfurt: Suhrkamp.

Luhmann, N. (1997). Die Gesellschaft der Gesellschaft [The society of society]. Frankfurt: Suhrkamp.

Luhmann, N. (2002). Einführung in die Systemtheorie [Introduction into systems theory]. Heidelberg: Auer. Luhmann, N. (2013). Introduction to systems theory. Cambridge and Malden, MA: Polity Press.

MacNeill, J. (2013). Brundtland revisited. Internation- 
al Institute for Sustainable Development. Retrieved from http://www.iisd.org/publications/brundtlandrevisited

Mathur, P. (2005). Neither cited nor foundational: Niklas Luhmann's 'Ecological Communication.' A critical exegesis and some theoretical suggestions for the future of a field. The Communication Review, 8, 329-362.

Mayntz, R. (2006). From government to governance: Political steering in modern societies. In D. Scheer \& F. Rubik (Eds.), Governance of integrated product policy: In search of sustainable production and consumption (pp. 18-25). Sheffield: Greenleaf Publishing.

Meadowcroft, J. (1999). The politics of sustainable development: Emergent arenas and challenges for political science. International Political Science Review, 20(2), 219-237.

Meadows, D. H., Meadows, D. L., Randers, J., \& Behrens, W. W. (1972). The limits to growth: A report for the Club of Rome's project on the predicament of mankind. New York, NY: Universe Books.

Ostrom, E. (1990). Governing the commons: The evolution of institutions for collective action. Cambridge, $\mathrm{NJ}$ : Cambridge University Press.

Parsons, T. (1951). The social system. Glencor, IL: Free Press.

Parsons, T. (1971). The system of modern societies. Englewood Cliffs, NJ: Prentice-Hall.

Polanyi, K. (1957). The great transformation. Boston, MA: Beacon Press. (Original work published 1944)

Radkau, J. (2000). Natur und Macht: Eine Weltgeschichte der Umwelt [Nature and power: A global history of the environment]. Munich: Beck.

Rosenau, J. N., \& Czempiel, E. O. (Eds.). (1992). Governance without government: Order and change in world politics. Cambridge and New York, NY: Cam- bridge University Press.

Schimank, U. (2005). Differenzierung und Integration moderner Gesellschaften [Differentiation and integration of modern societies]. Wiesbaden: Verlag für Sozialwissenschaften.

Schimank, U., \& Volkmann, U. (2015). Gesellschaftliche Differenzierung [Societal differentiation]. Bielefeld Transcript.

Schwietring, T. (2006). Geht es auch ohne? Zur Rolle des Kulturbegriffs in der Rational Choice-Theorie Hartmut Essers und in Niklas Luhmanns Theorie autopoietischer Systeme [Necessary, or not? On the role of the concept of culture in Hartmut Esser's theory of rational choice and Niklas Luhmann's theory of autopoietic systems]. In R. Greshoff \& U. Schimank (Eds.), Integrative Sozialtheorie? Esser, Luhmann, Weber [Integrative social theory? Esser, Luhmann, Weber] (pp. 187-227). Wiesbaden: VS Verlag für Sozialwissenschaften.

Steffen, W. L., Rockström, J., \& Costanza, R. (2011). How defining planetary boundaries can transform our approach to growth. Solutions: For a Sustainable \& Desirable Future, 2(3), 59-65.

Stichweh, R. (2000). Die Weltgesellschaft [The world society]. Frankfurt: Suhrkamp.

United Nations. (1987). Our common future: Report of the World Commission on Environment and Development. New York, NY: United Nations.

United Nations. (2015). Transforming our world: The 2030 Agenda for sustainable development: Resolution adopted by the General Assembly on 25 September 2015 (A/RES/69/315). New York, NY: United Nations.

White, L., Jr. (1967). The historical roots of our ecological crisis. Science, 155(3767), 1203-1207.

\section{About the Authors}

Dieter Konold is Researcher at Project Management Jülich, affiliated with Forschungszentrum Jülich. He is an Advisor to the German Federal Ministry of Education and Research. His focus of work is on bioeconomy and he was involved in developing the German National Bioeconomy Strategy. He holds a PhD in Political Science from the Humboldt University of Berlin where he was a Lecturer in International Relations. He studied Political Science and History in Freiburg and Salamanca.

Thomas Schwietring studied sociology and history at the Universities of Kassel, Manchester and Bielefeld. He received a PhD in sociology in 2003 and taught sociology at the University of Kassel, the Justus Liebig University Giessen and the University of Duisburg-Essen. His main focus is on the philosophy of social sciences, historical sociology and philosophical anthropology. He has worked at Project Management Jülich, affiliated with Forschungszentrum Jülich, since 2013, advising the German Federal Ministry of Education and Research. 